\title{
Influence of Integrated Nitrogen Management Practices on Yield Attributes, Yield, Nutrient Uptake and Economics of Hybrid Maize (Zea mays L.)
}

\author{
Yumnam Sanatombi Devi", Edwin Luikham, M. Sumarjit Singh, Jamkhogin Lhungdim \\ and Yendrembam Babila Chanu
}

\begin{abstract}
Department of Agronomy, College of Agriculture, Central Agricultural University, Iroisemba 795004, Imphal, Manipur, India
\end{abstract}

*Corresponding author

\section{A B S T R A C T}

\section{Keywords}

Integrated nitrogen management, Yield attributes, Yield and hybrid maize

Article Info

Accepted:

18 September 2018

Available Online:

10 October 2018
A field experiment entitled "Influence of Integrated Nitrogen Management Practices on yield attributes and yield of Hybrid Maize (Zea mays L.)" was conducted during the pre kharif season of 2015 at experimental field of College of Agriculture, Central Agricultural University, Imphal, Manipur. The experiment was laid-out in Randomized Block Design with 3 replications and consisted 11 treatments. Results indicated that application of $100 \%$ RDN + vermicompost 5 t/ha recorded highest number of cobs per plant (2.0), cob length $(19.98 \mathrm{~cm})$, cob girth $(16.93 \mathrm{~cm})$, number of grains per cob $(510.70)$ and test weight $(277.67 \mathrm{~g})$. Similar trends were observed in case of grain yield $(70 \mathrm{q} / \mathrm{ha})$ and stover yield $(91.20 \mathrm{q} / \mathrm{ha})$. Significantly higher uptake of nitrogen, phosphorus and potassium were recorded with the application of $100 \% \mathrm{RDN}+$ vermicompost $5 \mathrm{t} / \mathrm{ha}\left(\mathrm{T}_{7}\right)$. With regards to economics indices the highest monetary return was associated with the application of $100 \% \mathrm{RDN}+\mathrm{FYM} 5 \mathrm{t} / \mathrm{ha}\left(\mathrm{T}_{4}\right)$.

\section{Introduction}

Maize is the third important cereal crop next to the rice and wheat in the world. Maize has been an important cereal crop because of its high production potential compared to any other cereal crop. Since the crop has very high genetic yield potential, it is called as the "queen of cereals". Maize being a $\mathrm{C}_{4}$ plant has higher yield potential which also depends on nutrient supplying capacity of the soil. It is grown across a wide range of climatic conditions of the world due its wider adaptability (Amanullah et al., 2007). Maize is an exhaustive crop and therefore, needs adequate supply of nutrients particularly nitrogen for better growth and yield. Nitrogen is an integral part of chlorophyll, which is the primary absorber of light energy needed for photosynthesis and also impart vigorous vegetative growth, dark green colour to plants. Thus increasing vegetative growth results in higher green fodder production and grain yield. Well decomposed FYM in addition to supplying plant nutrients acts as binding materials and improves the soil physical properties. Manure acts as nutrient reservoir and upon decomposition, produces organic 
acids, thereby adsorbed ions are released slowly for the entire growth period leading to higher yield (Kumar et al., 2005). Vermicompost is an excellent base for the establishment of beneficial free living and symbiotic microbes. Application of vermicompost increases the total microbial population of nitrogen fixing bacteria that convert nutrient in soil into plant available form. Hybrid maize is a heavy feeder and is more responsive to applied nutrient. The required amount of nutrient may be supplied through organic manure and inorganic fertilizers to grow it and to maintain soil fertility on a sustained manner (Sarkar et al., 2000). Therefore, it needs fertile soil to express its yield potential. Among the major nutrient, nitrogen is considered to be one of most important nutrient for improving the productivity of hybrid maize.Integrated nutrient management system involves efficient and judicious supply, use and management of all the major components of plant nutrient sources. The integrated supply and use of plant nutrient from chemical fertilizer and organic manures can produce higher crop yield and helps to improve chemical, physical and biological properties of soil with no or minimal deleterious effect on environment. Thus, highest productivity of crops in sustainable manner without deteriorating the soil and other natural resources could be achieved only by applying appropriate combination of different organic manures and inorganic fertilizers (Chandrashekara et al., 2000). Therefore, keeping the above in view, the present investigation entitled "Influence of Integrated Nitrogen Management Practices on yield attributes and Yield of Hybrid Maize (Zea mays L.)" was undertaken.

\section{Materials and Methods}

A field experiment was conducted at Agronomy Research Farm of College of Agriculture, Central Agricultural University,
Imphal, Manipur during pre kharif season of 2015. The experimental site is situated at $24^{0}$ $45^{\prime} \mathrm{N}$ latitude and $93^{\circ} 56^{\prime} \mathrm{E}$ longitudes and at altitude of $790 \mathrm{~m}$ above the mean sea level. Representative soil samples were collected at random from the depth of $0-15 \mathrm{~cm}$ from several spots of the experimental field before starting the experiment and composited for mechanical and chemical analysis. The data indicated that the soil was clayey in texture having initial $\mathrm{pH}$ (5.6) (Glass electrode $\mathrm{pH}$ meter, Jackson, 1973) and organic carbon (1.77 \%) (Walkley and Black, 1934). The surface soil of the experimental field was found to be medium in available nitrogen (301.0 kg/ha), available phosphorus (20.20 $\mathrm{kg} / \mathrm{ha})$ and available potassium (230.54 $\mathrm{kg} / \mathrm{ha}$ ). The field experiment was laid out in randomized block design consisting of 11 treatments each replicated thrice. The treatments were $\mathrm{T}_{1}-100 \%$ recommended dose of nitrogen, $\mathrm{T}_{2}-75 \%$ recommended dose of nitrogen, $\mathrm{T}_{3}-50 \%$ recommended dose of nitrogen, $\mathrm{T}_{4}-100 \%$ recommended dose of nitrogen + FYM @ 5t / ha, T $-75 \%$ recommended dose of nitrogen + FYM @ 5t / ha, $\mathrm{T}_{6}-50 \%$ recommended dose of nitrogen + FYM @ 5t / ha, $\mathrm{T}_{7}-100 \%$ recommended dose of nitrogen + Vermicompost @ 5t / ha, $\mathrm{T}_{8}$ $75 \%$ recommended dose of nitrogen + Vermicompost @ 5t / ha, $\mathrm{T}_{9}-50 \%$ recommended dose of nitrogen + Vermicompost@5t / ha, T 10 - FYM @5t / ha, $\mathrm{T}_{11}$-Vermicompost@ 5t / ha. The experimental field was ploughed by a tractor and subsequently harrowed by power tiller to bring the field to a desirable tilth. High yielding hybrid variety PAC 740 was sown on 11 February 2015 using seed rate of $25 \mathrm{~kg} / \mathrm{ha}$. The seeds were placed at 3-4 cm depth at a spacing of $60 \mathrm{~cm}$ between rows and $20 \mathrm{~cm}$ between plants and then covered with thin layer of soil. The FYM and vermicompost was applied 20 days before sowing as per treatment and well incorporated to the soil. Recommended dose of nitrogen $(120 \mathrm{~kg} / \mathrm{ha})$ as 
per the treatments was calculated for each plot using urea, along with uniform dose of phosphorus $(60 \mathrm{~kg} / \mathrm{ha})$ through single super phosphate and potash (40 kg/ha) through muriate of potash were applied to the furrow a day before sowing of the crop at 5-6 cm depth. Half of the nitrogen along with full dose of phosphorus and potash according to the treatment were applied to the respective plots as basal dose and well mixed with soil. The remaining half dose of nitrogen was top dressed into equal splits at knee high stage and tasseling stage. One hand weeding along with interculture and earthing up were done 40 DAS for all the plots to keep the experimental site clean and reduce the crop weed competition. One pre-sowing irrigation was given for uniform germination of the crop. Subsequent irrigation followed at knee heigh and tasseling stage when top dressing of nitrogen was done. Initial soil analysis of nitrogen, phosphorus and potassium were done as per standard method (Subbiah and Asija, 1956 and Jackson, 1973). The crop was harvested on $22^{\text {nd }}$ June, 2015 from net plot area when the trash turns yellow and grains are hard with less moisture content. The husk was detached from the cobs and sun dried for a week. Thereafter, grains were separated from cobs manually. The grains were then sun dried for safe storage.

\section{Results and Discussion}

\section{Effect of integrated nitrogen management practices on yield attributes}

The number of cobs per plant increased significantly with combined application of inorganic fertilizer and organic manure. Maximum number of cobs per plant was observed in $100 \%$ RDN + vermicompost 5 $\mathrm{t} / \mathrm{ha}\left(\mathrm{T}_{7}\right)$. This increase in number of cobs per plant might be due to the fact that the combine effect of higher level of inorganic nitrogen along with organic source helped the crop in better nutrition and creation of congenial physical environment for better root growth as well as supply of growth promoting substances (Gibberellin and auxin). Similar finding was also reported by Kumar et al., (2007), and Choudhary and Kumar (2013).

The highest length of cob was recorded with the application of $100 \% \mathrm{RDN}+$ vermicompost $5 \mathrm{t} / \mathrm{ha}\left(\mathrm{T}_{7}\right)$. The possible reason could be better absorption of essential nutrients, synthesize phytohormone that promotes the cob length. The benefit of integrated nitrogen management on cob length of maize was also reported by Kumar et al., (2007) and Choudhary and Kumar (2013).

The cob girth increase with combine application of inorganic nitrogen and organic manure at higher dose. Maximum cob girth was recorded in the treatment $100 \%$ RDN + vermicompost $5 \mathrm{t} / \mathrm{ha}\left(\mathrm{T}_{7}\right)$. The results are in accordance with the earlier finding of Ravi et al., (2012).

Significant increase in number of grains per cob was recorded with higher dose of nitrogen combine with organic manure. Maximum number of grains per cob was observed in the treatment $100 \%$ RDN + vermicompost 5 t/ha $\left(\mathrm{T}_{7}\right)$.Minimum number of grains per cob was recorded in FYM 5 t/ha $\left(\mathrm{T}_{10}\right)$ where only organic manure was applied. The lesser numbers of grains might be due to inadequate supply of nitrogen from organic source alone which reduced biomass production traits of plant and ultimately reflecting to number of grains per cob. This result is in agreement with the earlier findings of Kumar et al., (2007), Dawadi and Sah (2012) and Kannan et al., (2013).

The test weight increased significantly with higher nitrogen level combined with organic manure. Maximum test weight was observed in treatment $100 \% \mathrm{RDN}+$ vermicompost 5 
t/ha $\left(\mathrm{T}_{7}\right)$. The results are in accordance with the finding of Kumar et al., (2007) and Kannan et al., (2013) (Table 1 and 2).

\section{Effect of integrated nitrogen management practices on yield}

The grain yield was significantly affected by the application of nitrogen at higher dose along with organic manure. Application of $100 \% \mathrm{RDN}+$ vermicompost $5 \mathrm{t} / \mathrm{ha}\left(\mathrm{T}_{7}\right)$. The soil sample analyzed before the start of the experiment also showed that the available nitrogen status of soil in the experiment site was in medium range $(301.00 \mathrm{~kg} / \mathrm{ha})$. Application of nitrogen combined with organic manure, therefore, provided better nutrition to maize which resulted in higher grain yield. Increase in grain yield with the application of nitrogen combined with organic manure may also be attributed to better growth of plant as expressed in terms of plant height, fresh weight and dry weight of plant and LAI which were favorably affected by inorganic and organic fertilization. Thus, the improvement in growth resulted in significant increase in yield attributes like number of cobs per plant, grains per cob, cob length and cob girth and test weight which ultimately contributed to higher grain yield. This findings are also supported by Nanjappa et al., (2001), Kumar et al., (2007), Dadarwal et al., (2009), Tahir et al., (2011), Shilpashree et al., (2012), Kannan et al., (2013) and Kumar (2014).

Stover yield increased significantly with the application of nitrogen and organic manure. The higher stover yield was associated with the application of $100 \% \mathrm{RDN}+$ vermicompost $5 \mathrm{t} / \mathrm{ha}\left(\mathrm{T}_{7}\right)$. This finding confirms the earlier report of Kumar et al., (2007) and Meena et al., (2007).

Table.1 Number of cobs/plant, cob length $(\mathrm{cm})$ and cob girth $(\mathrm{cm})$ of hybrid maize as influenced by integrated nitrogen management

\begin{tabular}{|c|c|c|c|c|c|}
\hline Treatment & $\begin{array}{l}\text { No. of } \\
\text { cobs/plant }\end{array}$ & $\begin{array}{l}\text { Cob } \\
\text { length } \\
\text { (cm) }\end{array}$ & $\begin{array}{l}\text { Cob } \\
\text { girth } \\
(\mathrm{cm})\end{array}$ & $\begin{array}{l}\text { No. of } \\
\text { grains } / \text { cob }\end{array}$ & $\begin{array}{l}\text { Test } \\
\text { weight(g) }\end{array}$ \\
\hline 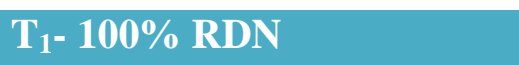 & 1.80 & 16.98 & 15.45 & 490.33 & 260.77 \\
\hline $\mathrm{T}_{2^{-}} \mathbf{7 5} \% \mathrm{RDN}$ & 1.34 & 13.22 & 14.29 & 471.03 & 250.13 \\
\hline $\mathrm{T}_{3^{-}} \mathbf{5 0 \%} \mathrm{RDN}$ & 1.13 & 11.08 & 13.95 & 450.77 & 239.47 \\
\hline $\mathrm{T}_{4}-100 \% \mathrm{RDN}+\mathrm{FYM}$ 5t/ha & 1.93 & 18.77 & 16.74 & 504.12 & 274.67 \\
\hline $\mathrm{T}_{5^{-}}$75\% RDN + FYM 5t/ha & 1.67 & 15.30 & 15.00 & 485.13 & 258.63 \\
\hline $\mathrm{T}_{6^{-}}$50\% RDN + FYM 5t/ha & 1.27 & 12.97 & 14.15 & 465.07 & 248.87 \\
\hline $\begin{array}{l}T_{7^{-}} \mathbf{1 0 0} \% \mathrm{RDN}+ \\
\text { Vermicompost 5t/ha } \\
\end{array}$ & 2.00 & 19.98 & 16.93 & 510.70 & 277.67 \\
\hline $\begin{array}{l}\mathrm{T}_{8-75}-\mathbf{R D N}+ \\
\text { Vermicompost } 5 \mathrm{t} / \mathrm{ha}\end{array}$ & 1.73 & 16.00 & 15.05 & 488.53 & 259.27 \\
\hline $\begin{array}{l}\mathrm{T}_{9-} \text { 50\% RDN + } \\
\text { Vermicompost 5t/ha } \\
\end{array}$ & 1.33 & 13.10 & 14.27 & 468.03 & 249.03 \\
\hline $\mathrm{T}_{10^{-}}$FYM 5t/ha & 1.00 & 9.07 & 12.80 & 435.37 & 229.80 \\
\hline $\mathrm{T}_{11^{-}}$Vermicompost 5t/ha & 1.00 & 9.23 & 13.00 & 440.03 & 233.67 \\
\hline S.Ed( $( \pm)$ & 0.05 & 0.85 & 0.59 & 3.73 & 2.48 \\
\hline $\mathrm{CD}(\mathrm{p}=0.05)$ & 0.10 & 1.77 & 1.24 & 7.78 & 5.16 \\
\hline
\end{tabular}


Table.2 Number of grains per cob and test weight ( $\mathrm{g}$ ) of hybrid maize as influenced by integrated nitrogen management

\begin{tabular}{|l|l|l|}
\hline Treatment & No. of grains/cob & Test weight (g) \\
\hline T1- 100\% RDN & 490.33 & 260.77 \\
\hline T2- 75\% RDN & 471.03 & 250.13 \\
\hline T3- 50\% RDN & 450.77 & 239.47 \\
\hline T4- 100\% RDN+ FYM 5t/ha & 504.12 & 274.67 \\
\hline T5- 75\% RDN + FYM 5t/ha & 485.13 & 258.63 \\
\hline T6- 50\% RDN + FYM 5t/ha & 465.07 & 248.87 \\
\hline T7- 100\% RDN + Vermicompost 5t/ha & 510.70 & 277.67 \\
\hline T8- 75\% RDN + Vermicompost 5t/ha & 488.53 & 259.27 \\
\hline T9- 50\% RDN + Vermicompost 5t/ha & 468.03 & 249.03 \\
\hline T10- FYM 5t/ha & 435.37 & 229.80 \\
\hline T11- Vermicompost 5t/ha & 440.03 & 233.67 \\
\hline S.Ed( \pm ) & 3.73 & 2.48 \\
\hline CD $($ p=0.05) & 7.78 & 5.16
\end{tabular}

Table.3 Nitrogen, phosphorus and potassium uptake (kg/ha) as influenced by integrated nitrogen management

\begin{tabular}{|c|}
\hline Treatment \\
\hline$\overline{T_{1}-100 \% \text { RDN }}$ \\
\hline $\mathrm{T}_{2^{-}} \mathbf{7 5} \% \mathrm{RDN}$ \\
\hline $\mathrm{T}_{3}-50 \% \mathrm{RDN}$ \\
\hline $\begin{array}{l}\text { Th- } 100 \% \text { RDN + FYM } 5 \\
\text { t/ha }\end{array}$ \\
\hline $\mathrm{T}_{5^{-}} 75 \% \mathrm{RDN}+\mathrm{FYM} 5 \mathrm{t} / \mathrm{ha}$ \\
\hline $\mathrm{T}_{6}-50 \% \mathrm{RDN}+\mathrm{FYM} 5 \mathrm{t} / \mathrm{ha}$ \\
\hline $\begin{array}{l}\mathrm{T}_{7^{-}} \quad 100 \% \\
\text { Vermicompost } 5 \mathrm{t} \text { t/ha }\end{array}$ \\
\hline $\begin{array}{l}\mathrm{T}_{8^{-}} \quad 75 \% \text { RDN } \\
\text { Vermicompost } 5 \mathrm{t} / \mathrm{ha}\end{array}$ \\
\hline $\begin{array}{lccc}T_{9-} & \mathbf{5 0} & \% & \mathrm{RDN} \\
\text { Vermicompost } & \mathbf{5} \text { t/ha }\end{array}$ \\
\hline $\mathrm{T}_{10^{-}}$FYM 5 t/ha \\
\hline $\mathrm{T}_{11}$ - Vermicompost $5 \mathrm{t} / \mathrm{ha}$ \\
\hline S.Ed( $( \pm)$ \\
\hline $\mathrm{CD}(\mathrm{p}=0.05)$ \\
\hline
\end{tabular}

\begin{tabular}{|l|l|l|}
\hline \multicolumn{3}{|c|}{ Uptake (kg/ha) } \\
\hline Nitrogen & Phosphorus & Potassium \\
\hline 123.87 & 23.30 & 138.98 \\
\hline 115.77 & 20.54 & 133.98 \\
\hline 104.30 & 17.17 & 101.39 \\
\hline 129.50 & 24.83 & 140.98 \\
\hline 121.60 & 21.33 & 135.53 \\
\hline 110.53 & 18.87 & 109.90 \\
\hline 131.37 & 25.46 & 142.70 \\
\hline 122.97 & 22.84 & 137.98 \\
\hline 114.77 & 19.66 & 122.53 \\
\hline 96.67 & 12.33 & 85.23 \\
\hline 97.97 & 13.35 & 92.75 \\
\hline $\mathbf{2 . 5 6}$ & $\mathbf{1 . 3 4}$ & $\mathbf{5 . 7 2}$ \\
\hline $\mathbf{5 . 3 4}$ & $\mathbf{2 . 8 0}$ & $\mathbf{1 1 . 9 5}$ \\
\hline
\end{tabular}


Table.4 Influence of integrated nitrogen management on economics of hybrid maize production

\begin{tabular}{|c|c|c|c|c|}
\hline Treatments & $\begin{array}{l}\text { Cost of } \\
\text { cultivation } \\
\text { (Rs/ha) }\end{array}$ & $\begin{array}{c}\text { Gross } \\
\text { income } \\
\text { (Rs/ha) }\end{array}$ & $\begin{array}{c}\text { Net return } \\
\text { (Rs/ha) }\end{array}$ & $\begin{array}{l}\text { B:C } \\
\text { Ratio }\end{array}$ \\
\hline $\mathrm{T}_{1}-100 \% \mathrm{RDN}$ & 32,979 & 111,535 & 78,556 & 2.38 \\
\hline $\mathrm{T}_{2^{-}} \mathbf{7 5} \% \mathrm{RDN}$ & 32,261 & 81,037 & 48,775 & 1.51 \\
\hline $\mathrm{T}_{3}-50 \% \mathrm{RDN}$ & 31,544 & 56,860 & 25,315 & 0.80 \\
\hline $\mathrm{T}_{4}-100 \% \mathrm{RDN}+\mathrm{FYM} 5 \mathrm{t} / \mathrm{ha}$ & 42,979 & 146,272 & 103,292 & 2.40 \\
\hline $\mathrm{T}_{5}-75 \% \mathrm{RDN}+\mathrm{FYM} 5 \mathrm{t} / \mathrm{ha}$ & 42,261 & 108,563 & 66,301 & 1.56 \\
\hline $\mathrm{T}_{6}-50 \% \mathrm{RDN}+\mathrm{FYM} 5 \mathrm{t} / \mathrm{ha}$ & 41,544 & 77,263 & 35,718 & 0.85 \\
\hline $\mathrm{T}_{7}-100 \% \mathrm{RDN}+$ Vermicompost $5 \mathrm{t} / \mathrm{ha}$ & 107,979 & 149,120 & 41,140 & 0.38 \\
\hline $\mathrm{T}_{8-} \mathbf{7 5} \% \mathrm{RDN}+$ Vermicompost $5 \mathrm{t} / \mathrm{ha}$ & 107,261 & 112,720 & 5,458 & 0.05 \\
\hline $\mathrm{T}_{9-50 \% \mathrm{RDN}+\text { Vermicompost } 5 \text { t/ha }}$ & 106,544 & 79,803 & $-26,741$ & -0.25 \\
\hline $\mathrm{T}_{10^{-}}$FYM 5 t/ha & 32,950 & 43,730 & 10,780 & 0.32 \\
\hline $\mathrm{T}_{11}$ - Vermicompost 5 t/ha & 97,950 & 45,203 & $-52,747$ & -0.53 \\
\hline
\end{tabular}

Effect of integrated nitrogen management practices on nutrient uptake

Different nitrogen management practices showed significant effect on the nitrogen, phosphorus and potassium uptake by the hybrid maize. The highest nitrogen, phosphorus and potassium uptake (131.37, 25.46 and 142.70 $\mathrm{kg} / \mathrm{ha}$ ) were associated with the application of $100 \% \mathrm{RDN}+$ vermicompost $5 \mathrm{t} / \mathrm{ha}\left(\mathrm{T}_{7}\right)$. The increase in nitrogen, phosphorus and potassium uptake might be due to adequate and balance availability of nutrients in soil which resulted in higher dry matter production as revealed in increased fresh weight and dry weight of plant. The minimal uptake of major nutrients was recorded in FYM 5 t/ha $\left(\mathrm{T}_{10}\right)$. These results confirm the earlier findings of Nanjapp et al., (2001) and Datta et al., (2003) (Table 3).

Effect of integrated nitrogen management practices on economics of hybrid maize production

The acceptance of innovated technology by the farmers ultimately depends on the economics involved in the production. Among the different indicators of monetary efficiency in any production system, the economics in terms of net returns and benefit cost ratio has a greater impact on the utility and acceptance of the technology. The price of inputs and farm produce change from time to time and place to place. Accordingly to agronomic management practices crop production also will be vary from one farmer fields to another farmer fields (Table 4).

In the present study, the highest cost of cultivation was noticed with the application of $100 \% \mathrm{RDN}+$ vermicompost 5 t/ha (Rs 107,979 /ha) followed by the application of $75 \% \mathrm{RDN}+$ vermicompost 5 t/ha (Rs 107,261/ha). Higher cost of cultivation was mainly due to the higher cost of vermicompost. Similar results of higher cost of cultivation are well documented by Kumar et al., (2007), Sujatha et al., (2008) and Choudhary et al., (2013) in hybrid maize.

Remarkably higher gross returns was obtained with the application of $100 \%$ RDN + vermicompost 5 t/ha (Rs 149,120/ha) which was closely followed by the treatment $100 \%$ RDN + FYM 5 t/ha (Rs 146,272/ha). The higher gross returns in this treatment are mainly attributed to higher grain and stover yield. Similarly, economic benefit of integrated nutrient management in maize was also reported by Negi et al., (1992). Through higher gross return was associated with $100 \%$ RDN + 
vermicompost $5 \mathrm{t} /$ ha however, maximum net return and $\mathrm{B}$ : $\mathrm{C}$ ratio was recorded in the treatment $100 \% \mathrm{RDN}+\mathrm{FYM} 5 \mathrm{t} / \mathrm{ha}\left(\mathrm{T}_{4}\right)$. The reason for higher economic benefit in this treatment $\left(\mathrm{T}_{4}\right)$ is due to lower cost of FYM as compared to vermicompost with the grain and stover yield remaining at par to one another $\left(\mathrm{T}_{4}\right.$ and $\mathrm{T}_{7}$ ) Similar results of higher net returns were recorded by studies carried out by Pathak et al., (2002), Saha and Mondal (2006), Sharma and Kumar (2009) and Jat et al., (2013) in hybrid maize also clearly indicated that higher monetary return was obtained with integration of inorganic and organic nutrient management.

The net return and $\mathrm{B}$ : $\mathrm{C}$ ratio recorded negative value in the treatment with either vermicompost alone $\left(\mathrm{T}_{11}\right)$ or $50 \% \mathrm{RDN}+$ vermicompost $5 \mathrm{t} / \mathrm{ha}$ $\left(\mathrm{T}_{9}\right)$. This may be attributed to lower yield and higher cost of the input (vermicompost) which in turn resulted in lower monetary return.

On the basis of results obtained from the present investigation it could be concluded that the hybrid maize variety "PAC 740" responded well to the application of either $100 \%$ RDN + vermicompost $5 \mathrm{t} / \mathrm{ha}$ or $100 \% \mathrm{RDN}+\mathrm{FYM} 5$ $\mathrm{t} / \mathrm{ha}$. However, from the economic point of view, the highest monetary benefit in terms of net return and $\mathrm{B}$ : $\mathrm{C}$ ratio was associated with the application of $100 \%$ RDN + FYM 5 t/ha. Further, higher monetary return could be achieved in the treatment with $100 \% \mathrm{RDN}+$ vermicompost $5 \mathrm{t} / \mathrm{ha}$, if the farmer produce vermicompost in the farm itself to reduce the cost of this input.

\section{References}

Amanullah, M.M., Hassan, M.J., Nawab, K. and Ali, A. (2007). Response of Specific Leaf Area (SLA), Leaf Area Index (LAI) and Leaf Area Ratio (LAR) of maize (Zea mays L.) to plant density, rate and timing of nitrogen application. World Applied Sci. J., 2(3): 235-243.

Chandrashekara, C.P., Harlapur, S.I., Murlikrishna, S. and Girijesh, G.K. (2000). Response of maize (Zea maize L.) to organic manures with inorganic fertilizers. Karnataka J. Agric. Sci., 13(1): 144-146.

Choudhary, V.K. and Kumar, P.S. (2013). Maize production, economics and soil productivity under different organic cource of nutrients in eastern Himalayan region, India. Int. J. Plant Production, 7(2): 167-186.

Dadarwal, R.S., Jain, N.K. and Singh, D. (2009). Integrated nutrient management in baby corn (Zea mays). Indian J. Agric. Sci., 79(12): 1023-1025.

Datta, N., Sharma, R.P. and Sharma, G.D. (2003). Effect of supplementary use of FYM along with chemical fertilizers on productivity and nutrient uptake by vegetable pea and nutrient build up to soil fertility in Lahual valley of Himachal Pradesh. Indian J. Agric. Sci., 73: 266-68.

Dawadi, D.R. and Sah, S.K. (2012). Growth and yield of hybrid maize (Zea mays L.) in relation to planting density and nitrogen levels during winter season in Nepal. Trop. Agric. Res., 23(3): 218-227.

Jackson, M.L. (1973). Soil Chemical Analysis. Prentice hall of India Pvt. Ltd., New Delhi: 151-154.

Jat, M.K., Purohit, H.S., Singh, B., Gargwal, R.S. and Choudhary, M. (2013) Effect of integrated nutrient management on yield and nutrient uptake in sorghum (Sorghum bicolar). Indian J. Agron., 58(4): 543547.

Kannan, R.L., Dhivya, M., Abinaya, D., Krishna, R.L. and Kumar, S.K. (2013). Effect of Integrated Nutrient Management on Soil Fertility and Productivity in Maize. Bull. Env. Phamacol. Life Sci., 2(8): 61-67.

Kumar, A., Guatam, R.C. Singh, R. and Rana, R.S. (2005). Growth, yield and economics of maize (Zea mays) - wheat (Triticum aestivum) cropping sequence as influenced by integrated nutrient management. Indian J. Agric. Sci., 75(11): 709-711.

Kumar, P., Halepyati, A.S., Pujari, B.T. and Desai, B.K. (2007). Effect of integrated 
nutrient management on productivity, nutrient uptake and economics of maize (Zea mays) under rainfed condition. Karnataka J. Agric. Sci., 20(3): 462-465.

Kumar, S. V. (2014). Effect of integrated nutrient management on soil fertility and yield of maize crop (Zea mays L.) in EnticHaplustart in Tamil Nadu, India. $J$. Applied Natural Sci., 6(1): 294-297.

Meena, O., Khafi, H.R., Shekh, M.A., Mehta, A.C. and Davda, B.K. (2007). Effect of vermicompost and nitrogen on content, uptake and yield of rabi maize. Crop Res., 33(1, 2 and 3): 53-54.

Nanjappa, H.V., Ramachandrappa, B.K. and Mallikarjuna, B.O. (2001). Effect of integrated nutrient management on yield and nutrient balance in maize (Zea mays). Indian J. Agron., 46(4): 698-701.

Negi, S.C., Singh, K.K. and Thakur, R.C. (1992). Effect of phosphorus with and without FYM on yield and uptake of N, P and Protein content in wheat-maize sequence. Him. J. Agric. Res., 18: 5-8.

Pathak, S.K., Singh, S.B., and Singh, S.N., (2002) Effect of integrated nutrient management on growth, yield and economics in maize (Zea mays L.) Wheat (Tritiucum aestivum) cropping system. Indian J. Agron., 47(3): 325-332.

Pawar, R.B. (1996). Dynamics of earthwormsoil-plant relationship in semi-arid tropics pH.D. Thesis, Univ. Agric. Sc., Dharwad.

Ravi, N., Basavarajappa, R., Harlapur, S.I. and Hosamani, M.H. (2012). Effect of integrated nutrient management on growth and yield of quality protein maize. Karnataka J. Agric. Sci., 25(3): 395-396.
Saha, M. and Mondal, S.S. (2006). Influence of integrated plant nutrient supply on growth, productivity and quality of baby corn (Zea mays) in Indo-Gangetic plains. Indian J. Agron., 51(3): 202-205.

Sarkar, A.K., Singh, K.P., Singh, B.P. and Singh, R.P. (2000). Long term effects of fertilizers, manures and amendments on crop production and soil fertility. Tech. Bull. Soil Sci. Agric. Chemistry, pp.31-45.

Sharma, A. and Kumar, A. (2009). Effect of organics and integrated nutrient management on productivity and economics of rabi Sorghum. Karnataka J. Agric. Sci., 22(1): 11-14.

Shilpashree, V.M., Chidanandappa, H.M., Jayaprakash, R. and Punitha, B.C. (2012). Influence of integrated nutrient management practices on productivity of maize crop. Indian J. Fundamental Applied Life Sci., 2(1): 45-50.

Subbiah, B.Y. and Asija, G.L. (1956). A rapid estimation of available nitrogen in soils. Curr. Sci., 25: 259-260.

Sujatha, M.G., Lingaraja, B.S., Palleb, Y.B. and Ashalatha, K.V. (2008). Influence of integrated nutrient management practices in maize under rainfed condition. Karnataka J. Agric. Sci., 21(3): 334-338.

Tahir, M., Ayub, M., Javeed, H.M.R., Naeem, M., Rehman, H., Waseem, M. and Ali, M. (2011). Effect of different organic matter on growth and yield of wheat (Triticum aestivum). Pak. J. Life Social Sci., 9: 6366.

Walkley, A.J. and Black, T.A. (1934). Estimation of soil organic carbon by the chromic and titration method. Soil Sci., 37: 29-38.

\section{How to cite this article:}

Yumnam Sanatombi Devi, Edwin Luikham, M. Sumarjit Singh, Jamkhogin Lhungdim and Yendrembam Babila Chanu. 2018. Influence of Integrated Nitrogen Management Practices on Yield Attributes, Yield, Nutrient Uptake and Economics of Hybrid Maize (Zea mays L.). Int.J.Curr.Microbiol.App.Sci. 7(10): 2469-2476. doi: https://doi.org/10.20546/ijcmas.2018.710.286 